\title{
Drying of Agaricus bisporus Mushroom in Solar-Biogas Hybrid Dryer
}

\author{
Pradip Narale ${ }^{1 *}$, Surendra Kothari ${ }^{2}$ and Nafisa Ali ${ }^{2}$
}

${ }^{1}$ ICAR-AICRP on EAAI, Central Institute of Agricultural Engineering, Nabi Bagh, Berasia Road, Bhopal-462038 (MP), India

${ }^{2}$ Department of Renewable Energy Engineering, College of Technology and Engineering, Maharana Pratap University of Agricultural and Technology, Udaipur-313001

(Rajasthan), India

*Corresponding author

\section{A B S T R A C T}

\begin{tabular}{|l|}
\hline Ke y w o r d s \\
$\begin{array}{l}\text { Drying, Button } \\
\text { mushroom, Hybrid } \\
\text { dryer, Solar, Biogas } \\
\text { etc. }\end{array}$ \\
\hline Article Info \\
\hline $\begin{array}{l}\text { Accepted: } \\
\text { 16 March } 2018 \\
\text { Available Online: } \\
\text { 10 April } 2018\end{array}$ \\
\hline \hline
\end{tabular}

Introduction

The button mushroom (Agaricus bisporus) is the most widely cultivated and consumed mushroom throughout the world and it contributes about $40 \%$ of the total world production of mushroom. The white button mushroom still contributing about $90 \%$ of total country's production as against its global share of about $40 \%$ (Rai and Arumuganthan, 2003). As a high-class food, button mushrooms not only provide delicious taste but also possess abundant nutritive value
The button mushroom was dried from moisture content of $91 \%$ (wb) to $8.257 \%$ (wb) in 11 hours with average solar radiations availability of $560 \mathrm{~W} / \mathrm{m}^{2}$ and biogas consumption of $700 \mathrm{~L}$. Average $50.87{ }^{\circ} \mathrm{C}, 50.09{ }^{\circ} \mathrm{C}, 49.22{ }^{\circ} \mathrm{C}$, and $48.26{ }^{\circ} \mathrm{C}$ temperature was maintained throughout drying period in tray 1 , tray 2 , tray 3 , and tray 4 respectively. Tray 1 was bottom tray of the dryer, tray 2 was $2^{\text {nd }}$ tray from the bottom; tray 3 was $3^{\text {rd }}$ tray from bottom whereas tray 4 was top tray of dryer. Drying rate during process varies from 0.368 to $0.000139 \mathrm{~g}$ of water evaporated/g of dry matter for tray $1,0.368$ to $0.000213 \mathrm{~g}$ of water evaporated/g of dry matter for tray 2 whereas for tray 3 it was 0.367 to $0.000231 \mathrm{~g}$ of water/g of $\mathrm{dm}$ and for tray 4 it was 0.366 to $0.000231 \mathrm{~g}$ of water/g of $\mathrm{dm}$. The variation in ln (MR) with drying time for each tray was found to be linear with inverse slope. At all levels straights lines were fitted satisfactory with coefficient of determination $R^{2}>0.98$ was observed for drying of button mushroom.

(Cremades et al., 2012). However, the cultivated button mushroom is a highly perishable vegetable, having a very short shelf-life especially in summer (Oliveira et al., 2012; Sommer et al., 2010). Since these mushrooms have very short shelf life, these cannot be stored or transported for more than 24 hours at the ambient conditions prevailing in most parts of year and the country.

Mushroom is a rich source of good quality proteins having most of the essential amino acids, vitamins and minerals and is popular for 
its delicacy and exotic flavour (Rai et al., 2003). Indian diet, essentially vegetarian, supplemented with highly digestible superior quality mushroom protein will help eradicate malnutrition in our country. Realizing the importance of mushrooms to fight malnutrition, poverty and to manage agrowaste, FAO has recommended mushrooms for developing countries to bridge the protein gap (Nehru and Kumar, 1995).

Having a high protein value, mushrooms are foodstuffs that are used as garniture in vegetable and meat dishes and in soup making. Ground mushrooms as flour are used in the medical industry.

In order to keep mushrooms safe and unspoiled for a long time, it is vital to remove the bacteria causing fermentation or decomposition from their environment and from their structure. So, this bacterium should be killed and their contact with mushrooms cut. Drying is the oldest preservation technique of agricultural products. Drying is a widely employed preservation method to prevent the different types of spoilage including enzymatic or non-enzymatic browning and microbial growth by reducing the moisture content to a level for safe storage.

\section{Materials and Methods}

Mushroom of Agaricus bisporus (button mushroom) having about $87-91 \%$ moisture content (wb), were procured on daily basis from All India Co-ordinated Research Project (AICRP) on Mushroom, Rajasthan College of Agriculture, Maharana Pratap University of Agriculture and Technology, Udaipur, Rajasthan. Freshly harvested, firm, dazzling white, mature mushrooms of uniform size were manually sorted and selected as the raw material for experiment. The white button mushroom (Agaricus bisporus) of uniform size was thoroughly washed under tap water to remove adhering impurities. They were then dried on a blotting paper, and then samples of button mushroom were cut into $5 \pm 0.5 \mathrm{~mm}$ thick slices with the help of sharp stainless steel knife. Button mushroom samples were pretreated with mixture of $0.5 \%$ citric acid and $0.5 \%$ ascorbic acid before drying (Nour et al., 2011).

Moisture content of fresh as well as dried mushroom slices was determined by method suggested by Ranganna (2000).

$M C(\% d b)=\frac{M-M_{d}}{M_{d}} \times 100$

Where,

$\mathrm{M}=$ mass of original sample, $\mathrm{g}$

$M_{d}=$ mass of sample after drying, $g$

Availability of solar radiations $\left(\mathrm{W} / \mathrm{m}^{2}\right)$ were measured continuously during the process of drying of button mushroom. Biogas consumption in litre was also measured using analog type of biogas flow meter.

Moisture content of mushroom slices (db) during drying experiment was determined by the following equation;

Percent moisture content (db) $=\frac{\mathrm{M} \theta-M_{d}}{M_{d}} \times 100$

Where,

$\mathrm{M}_{\theta}=$ Mass of the sample at time $\theta, \mathrm{g}$

$\mathrm{M}_{\mathrm{d}}=$ Mass of the dry sample, $\mathrm{g}$

The moisture content data recorded during experiments were analyzed to determine the moisture lost by sample of mushroom slices in particular time interval. The drying rate of sample was calculated by following mass balance equation. 


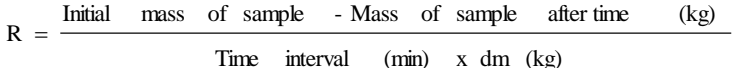

Where, $\mathrm{R}=$ Drying rate at time $\theta$

The dry matter (per cent) and mass of dry matter in sample were calculated using following equation:

Dry matter $(\mathrm{dm})(\%)=100.0-$ Initial Moisture Content (wb)

Weight of $\mathrm{dm}=$ Initial $\quad$ mass of sample $\times \frac{d m(\%)}{100}$

\section{Results and Discussion}

Full load performance of system was evaluated by loading dryer after pretreatment and slicing with $4 \mathrm{~kg}$ of button mushroom. It has been observed that moisture content of button mushroom was reduced with time. The button mushroom was dried from moisture content of $91 \%(\mathrm{wb})$ to $8.26 \%$ (wb) in 11 hours with average solar radiations availability of $560 \mathrm{~W} / \mathrm{m}^{2}$ and biogas consumption of 700 L. Average $50.87{ }^{\circ} \mathrm{C}, 50.09{ }^{\circ} \mathrm{C}, 49.22{ }^{\circ} \mathrm{C}$, and $48.26{ }^{\circ} \mathrm{C}$ temperature was maintained throughout drying period in tray 1 , tray 2 , tray 3 , and tray 4 respectively. Tray 1 was bottom tray of the dryer, tray 2 was $2^{\text {nd }}$ tray from the bottom; tray 3 was $3^{\text {rd }}$ tray from bottom whereas tray 4 was top tray of dryer. Average $43.13{ }^{\circ} \mathrm{C}$ temperature was observed at the outlet of chimney throughout drying time. Figure 2 shows variation of temperature $\left({ }^{\circ} \mathrm{C}\right)$ and solar radiations $\left(\mathrm{W} / \mathrm{m}^{2}\right)$ with respect to time (h) during drying of button mushroom. From Figure 2 it was clear that availability of solar radiation was low in morning and evening and was peak in afternoon. From Figure 3 it was observed that $165 \mathrm{~L}$ of biogas was consumed in morning when availability of solar radiations $\left(\mathrm{W} / \mathrm{m}^{2}\right)$ was insufficient to maintain average $50{ }^{\circ} \mathrm{C}$ inside dryer. It was observed that after $4 \mathrm{pm}$ availability of solar radiations $\left(\mathrm{W} / \mathrm{m}^{2}\right)$ was lower which was insufficient to maintain average $50^{\circ} \mathrm{C}$ temperature therefore $535 \mathrm{~L}$ of biogas was consumed during this drying period to maintain required temperature inside dryer. Figure 4 shows variation of temperature $\left({ }^{\circ} \mathrm{C}\right)$ and biogas consumption (L) with respect to time (h) during drying of button mushroom. From Figure 4 it was cleared that initially temperature inside dryer was low therefore biogas was consumed along with solar radiations to boost temperature up to $50{ }^{\circ} \mathrm{C}$ from initial low temperature. After 10am, average $50^{\circ} \mathrm{C}$ temperature was maintained inside dryer throughout drying period. Dried button mushroom with moisture content of $8.26 \%$ (wb) was shown in Figure 5.

Figure 6 reveals the moisture removal rate from button mushroom. The drying behavior follows the typical drying curves for the button mushroom. Button mushroom was dried from moisture content of $91 \%$ (wb) to $8.26 \%$ (wb) within 11 hours. Initially moisture content was decreased drastically with high drying rate up to initial 4 hours of drying period later on drying was took place slowly with nearly constant drying rate. From Figure 6 it was also cleared that moisture content of button mushroom in the tray 1 (bottom tray of dryer) was decreased with faster drying rate as compare to tray $2\left(2^{\text {nd }}\right.$ tray from bottom). Likewise moisture content of the product in tray 2 was decreasing in faster rate than product in tray 3 . Product in tray 4 was drying at slower rate as compare to product in other tray 1 , tray 2 , and tray 3 .

From Figure 7 it was found that drying rate during process varies from 0.368 to 0.000139 $\mathrm{g}$ of water evaporated/g of dry matter for tray1, 0.368 to $0.000213 \mathrm{~g}$ of water evaporated/g of dry matter for tray 2 whereas for tray 3 it was 0.367 to $0.000231 \mathrm{~g}$ of water/g of $\mathrm{dm}$ and for tray 4 it was 0.366 to $0.000231 \mathrm{~g}$ of water/g of $\mathrm{dm}$. 
Fig.1 Button mushroom used in investigation (Agaricus bisporus)

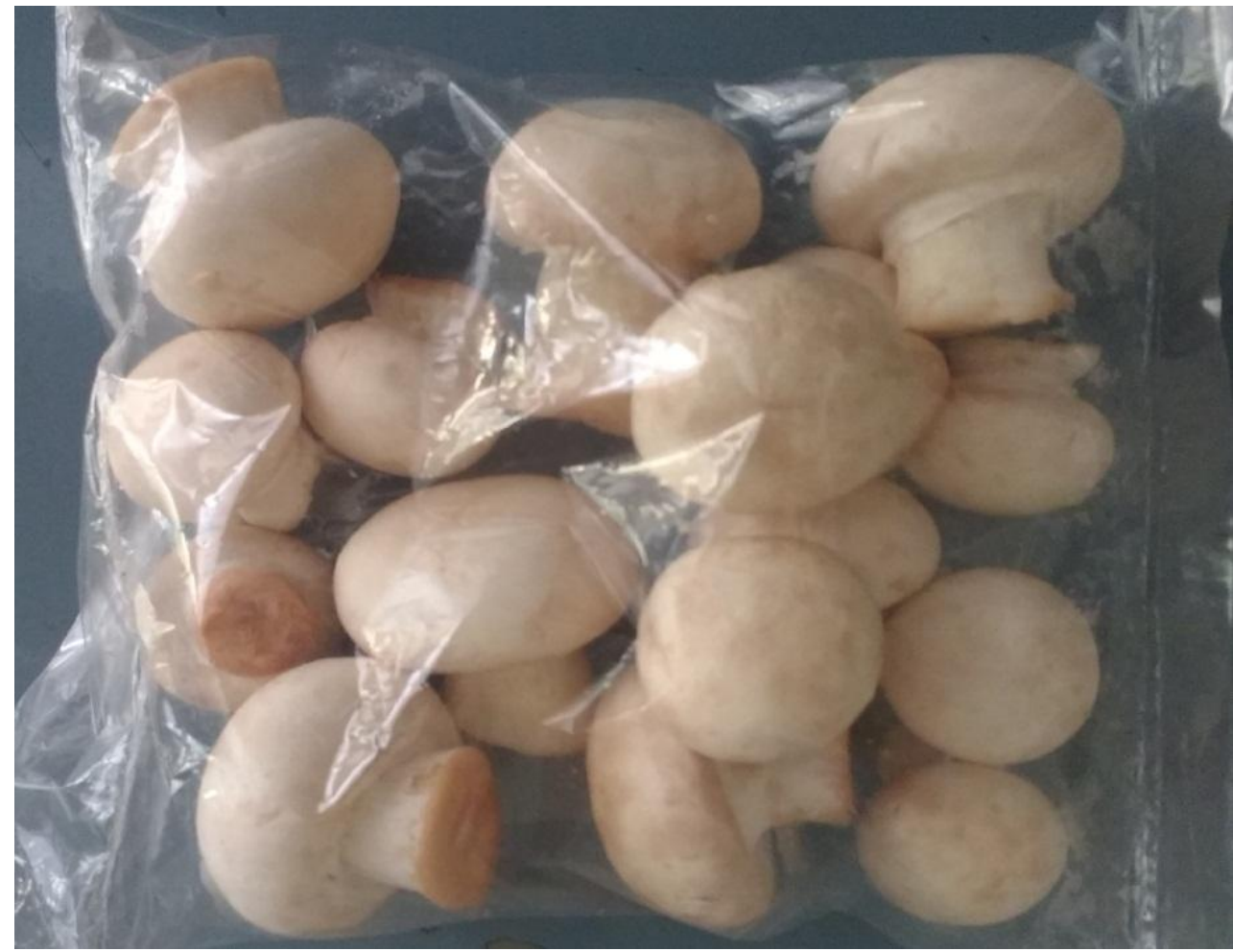

Fig.2 Variation of temperature $\left({ }^{\circ} \mathrm{C}\right)$ and solar radiations $\left(\mathrm{W} / \mathrm{m}^{2}\right)$ with respect to time $(\mathrm{h})$ during drying of button mushroom

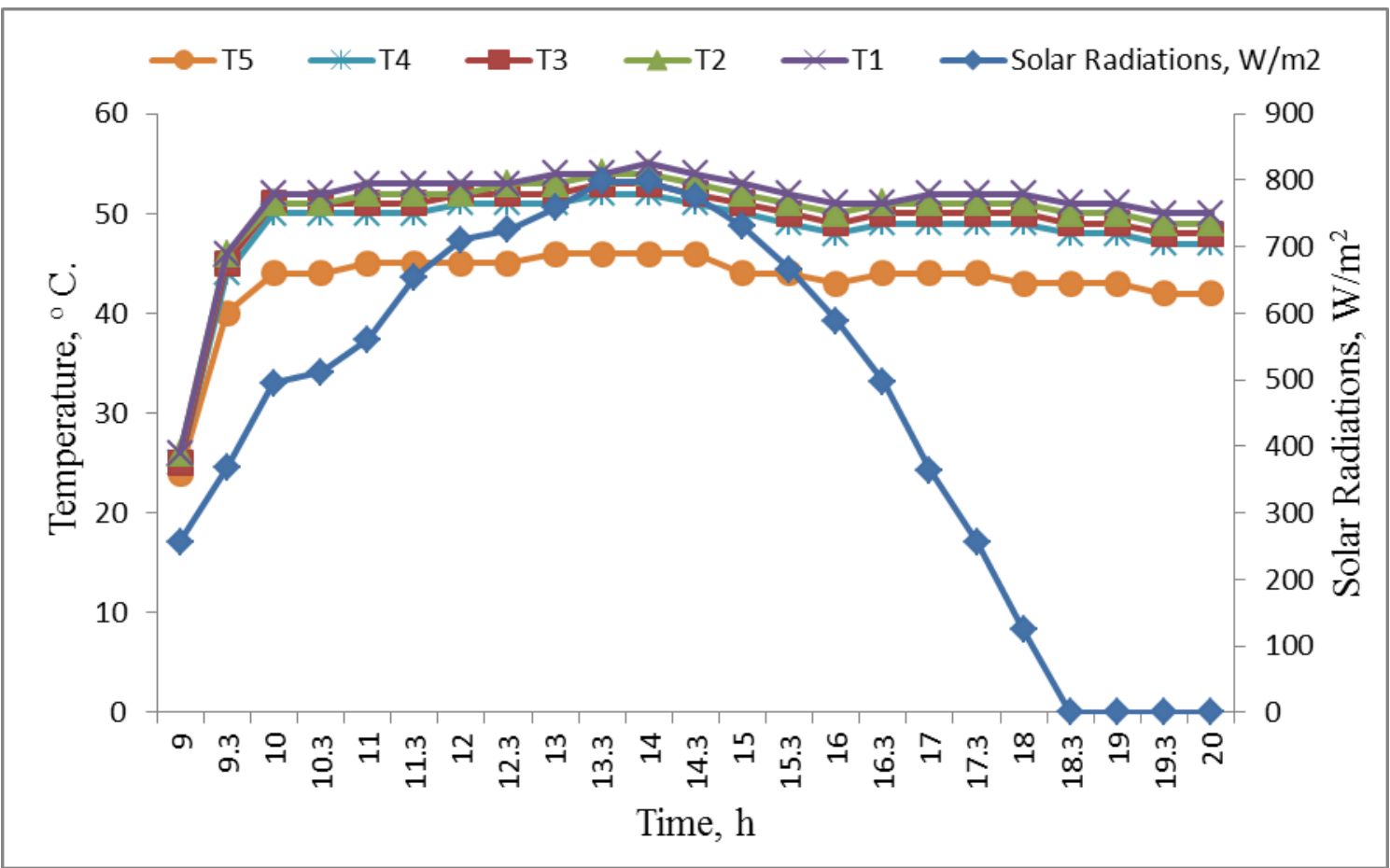


Fig.3 Biogas consumption (L) and availability of solar radiations $\left(\mathrm{W} / \mathrm{m}^{2}\right)$ with respect to time (h)

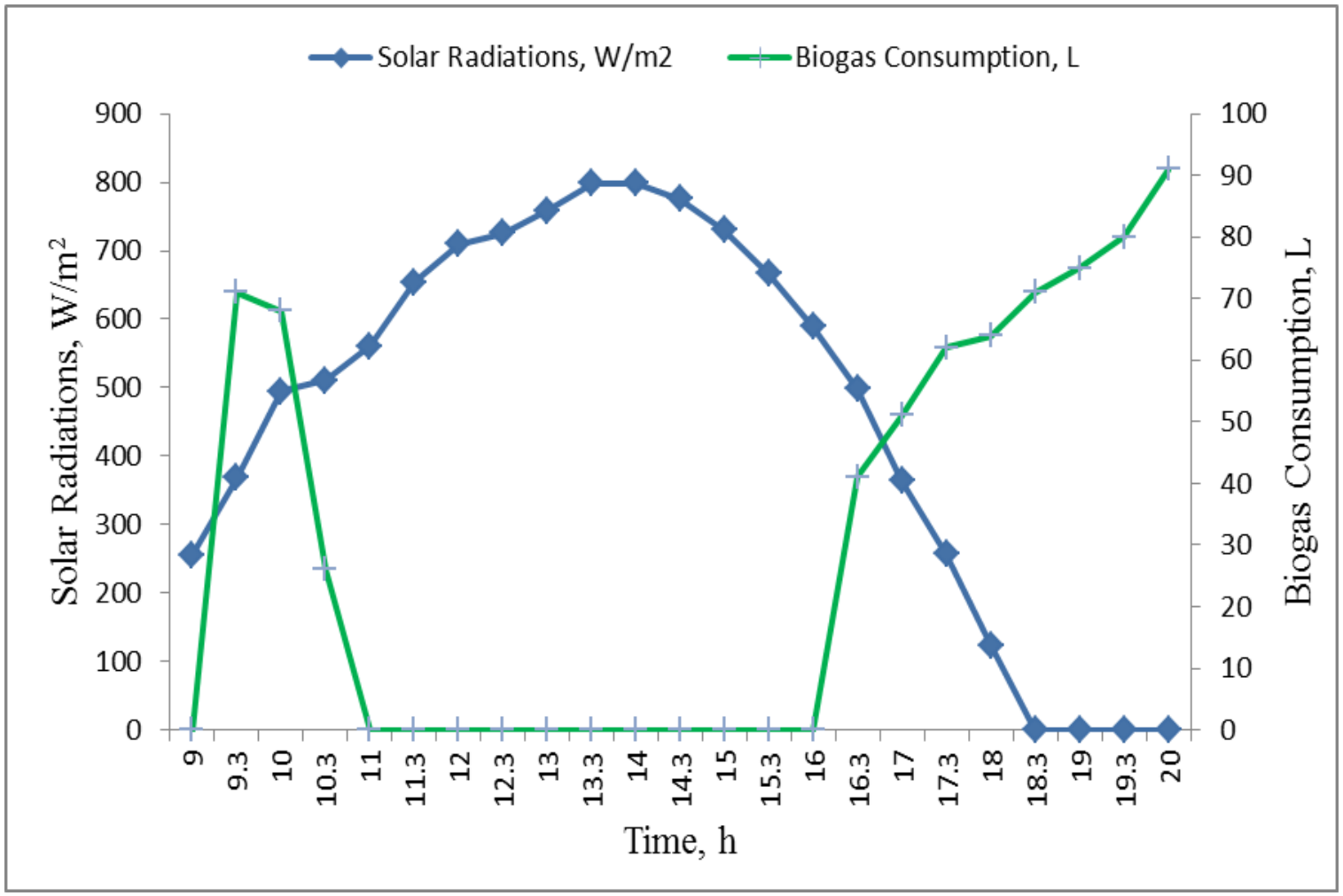

Fig.4 Variation of temperature $\left({ }^{\circ} \mathrm{C}\right)$ and biogas consumption $(\mathrm{L})$ with respect to time $(\mathrm{h})$ during drying of button mushroom

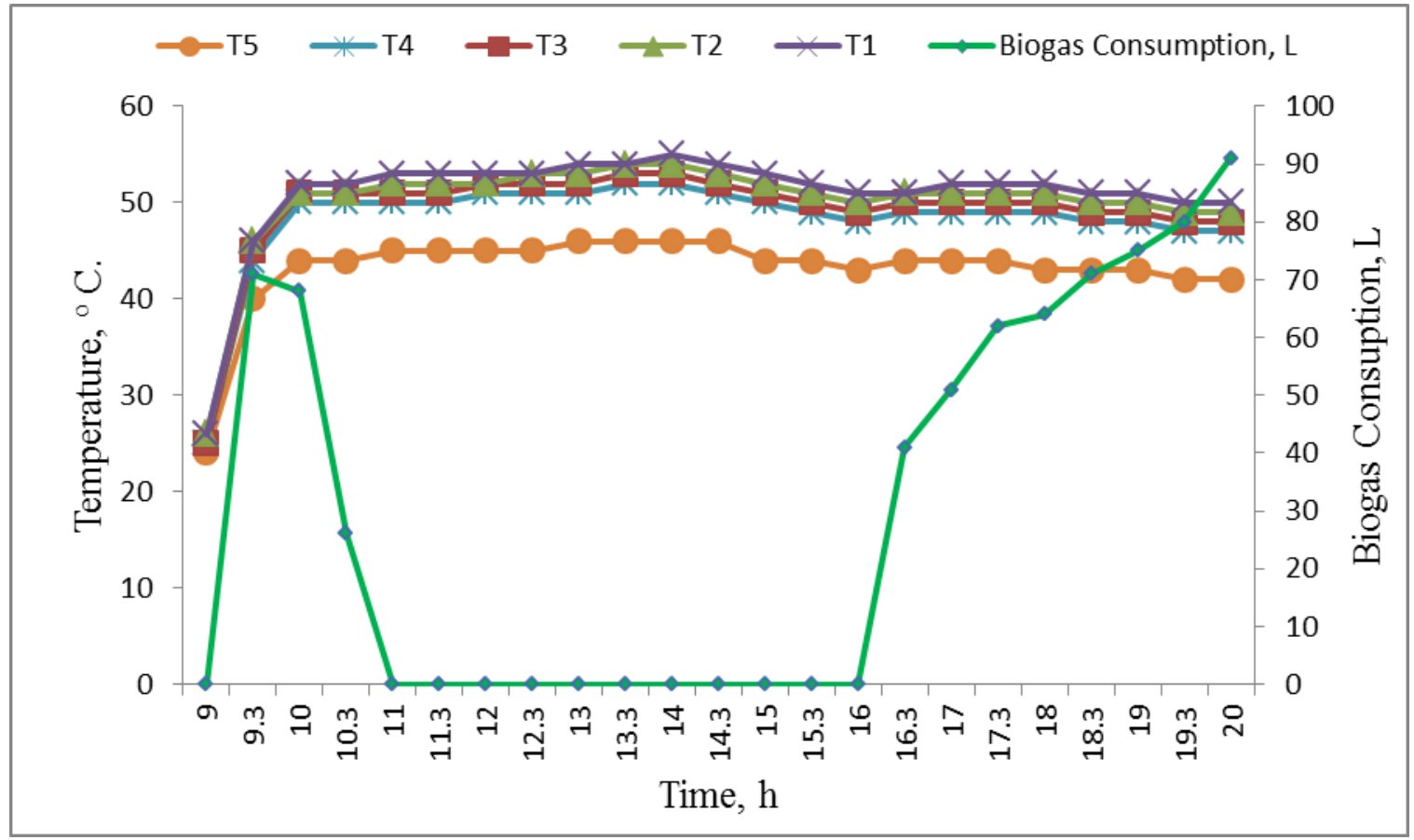


Fig.5 Dried button mushroom (Agaricus bisporus)

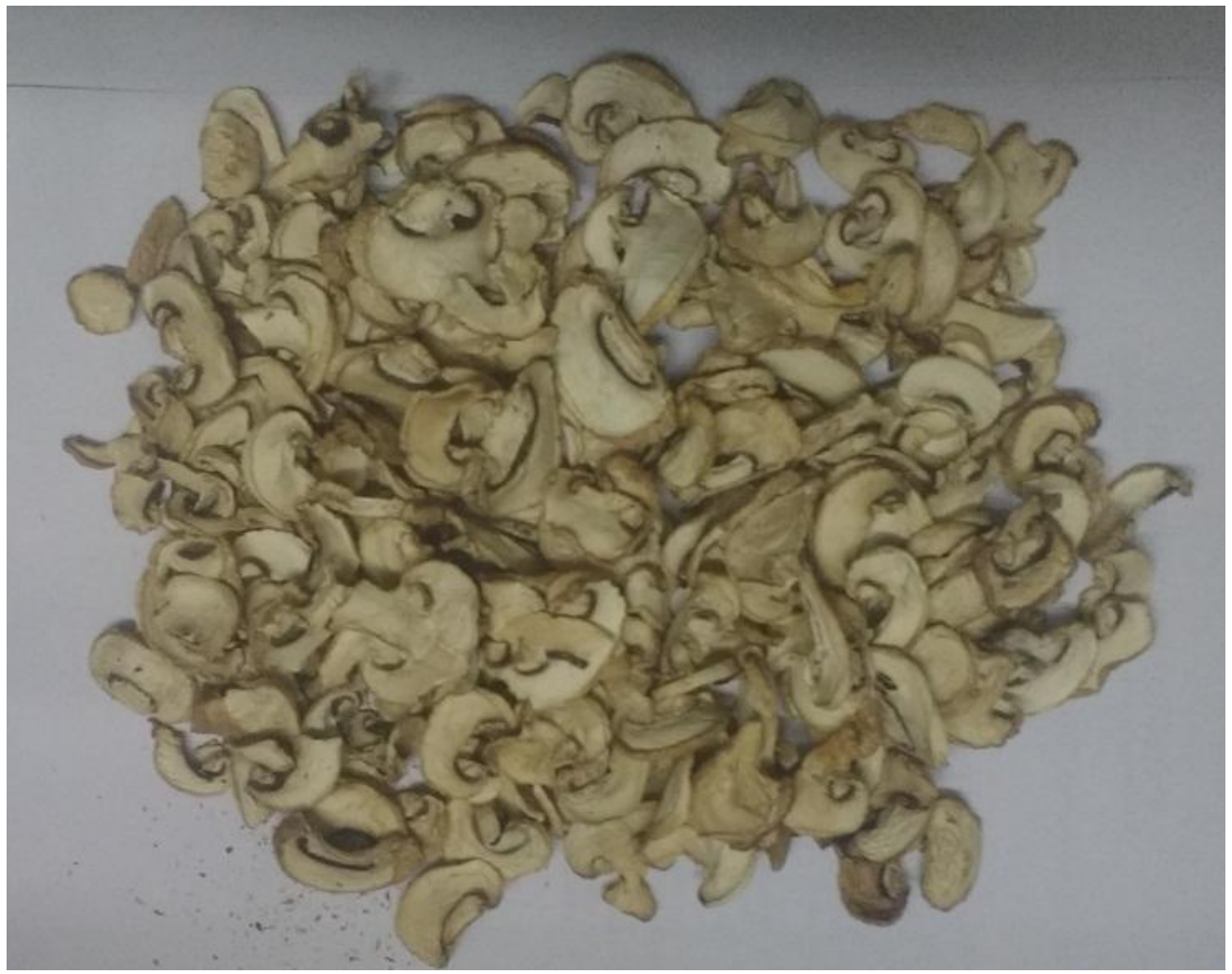

Fig.6 Variation of moisture content of button mushroom with drying time

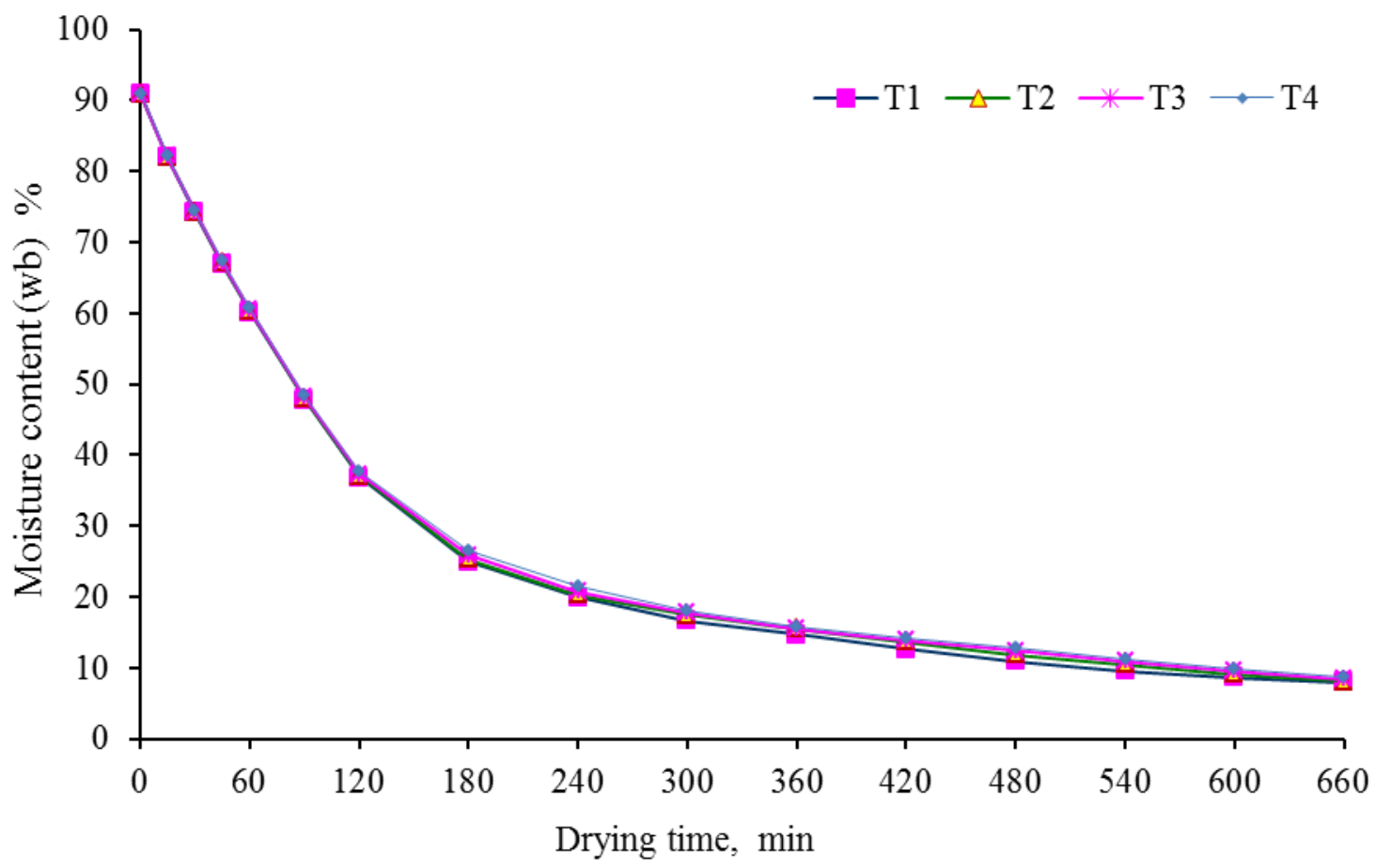


Fig.7 Drying rate of button mushroom with drying time

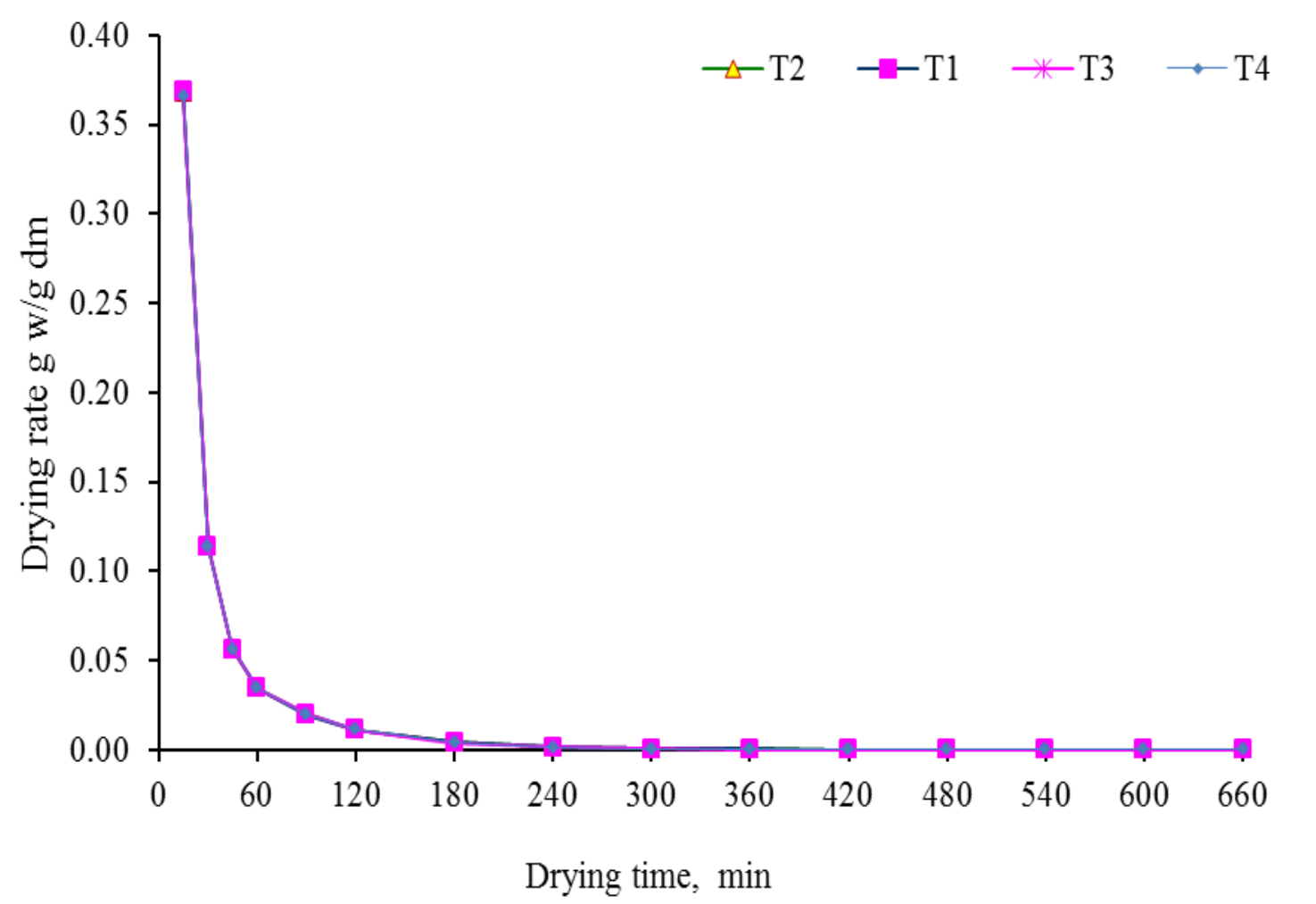

Fig.8 Drying rate of button mushroom with moisture content (wb\%)

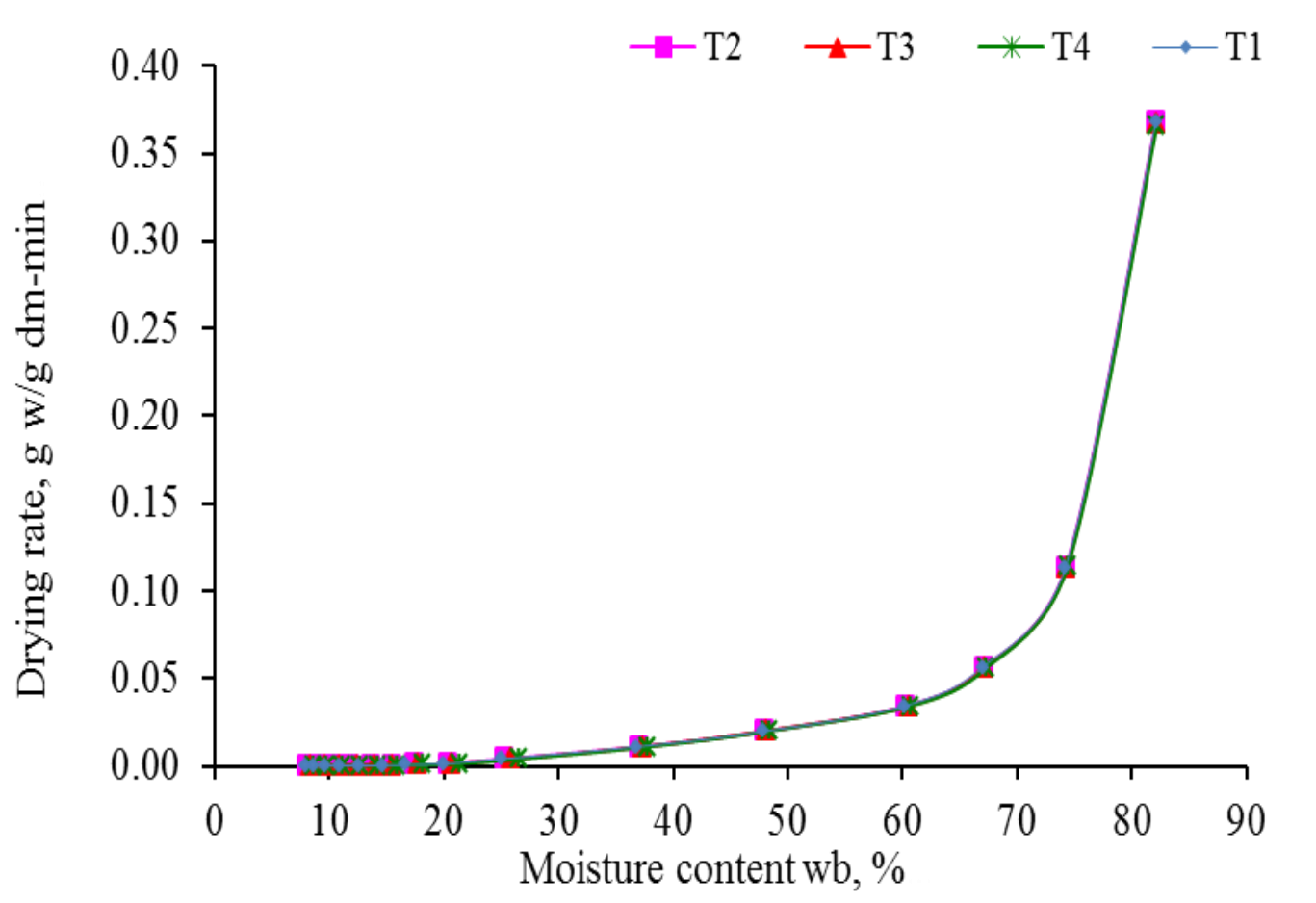


Fig.9 Variation in $\ln (\mathrm{MR})$ with drying time (t) at different tray during drying of button mushroom

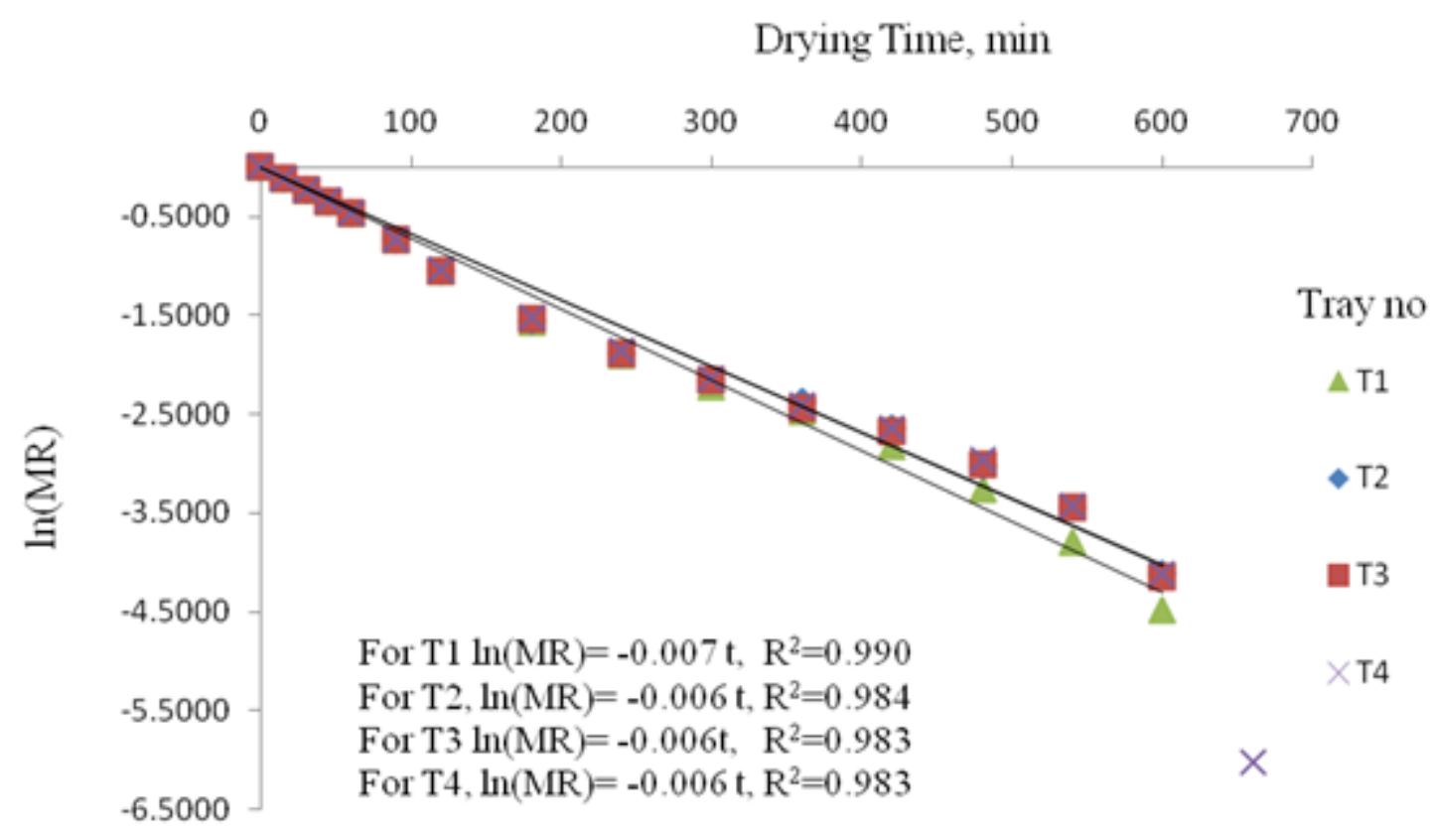

It was observed from Figure 7 that during initial three hours of operation graph remains steeper that means during initial three hours moisture removal rate was higher. After initial three hours of drying the drying rate curve was near to perfect horizontal line, it reveals that drying rate decreases rapidly and remains nearly constant for remaining drying hours.

Figure 8 shows variation of drying rate with respect to moisture content in percentage (wb). It was cleared from the vertical line in Figure 8 that initially moisture content was decreasing with higher drying rate as drying proceeds. Initially drying rate was high and it was decreases rapidly with reduction of moisture content. Moisture content in tray 1 was reduced from $91 \%$ (wb) to $7.93 \%$ (wb) whereas drying rate was reduced from 0.368 to $0.000139 \mathrm{~g}$ of water evaporated $/ \mathrm{g}$ of dry matter. Moisture content in tray 2 was reduced from $91 \%(\mathrm{wb})$ to $8.07 \%$ (wb) whereas drying rate was reduced from 0.368 to $0.000213 \mathrm{~g}$ of water evaporated/g of dry matter. Moisture content in tray 3 was reduced from $91 \%(\mathrm{wb})$ to $8.40 \%$ (wb) whereas drying rate was reduced from 0.367 to $0.000231 \mathrm{~g}$ of water evaporated/g of dry matter. Moisture content in tray 4 was reduced from $91 \%(\mathrm{wb})$ to $8.63 \%$ (wb) whereas drying rate was reduced from 0.366 to $0.000231 \mathrm{~g}$ of water evaporated/g of dry matter.

Drying data of button mushroom drying was also analyzed based on logarithmic equation of moisture ratio as shown below.

$\mathrm{MR}=\exp (-\mathrm{kt})$, where $\mathrm{k}$ is drying constant and $\mathrm{t}$ is time.

$\ln (\mathrm{MR})=-\mathrm{kt}$

The data was plotted on log graph with $\log$ (MR) on $\mathrm{Y}$-axis and time $\mathrm{t}$ on $\mathrm{X}$-axis as shown in Figure 9. Linear line was fitted and 
the value of $\mathrm{k}$ was found. The variation in $\mathrm{ln}$ (MR) with drying time for each tray was found to be linear with inverse slope as it has been presented in Figure 9. At all levels straights lines were fitted satisfactory with coefficient of determination $\mathrm{R}^{2}>0.98$ was observed for drying of button oyster mushroom.

\section{Acknowledgement}

Authors are highly thankful to Department of Renewable Energy Engineering, College of Technology and Engineering, Maharana Pratap University of Agriculture and Technology, Udaipur (Rajasthan), India for providing necessary facilities and financial support to carry out this research work.

\section{References}

Cremades, O., Diaz-Herrero, M. M., Carbonero-Aguilar, P., Gutierrez- Gil, J. F., Fontiveros, E., Rodríguez-Morgado, B. 2012. Preparation and characterisation of selenium-enriched mushroom aqueous enzymatic extracts (MAEE) obtained from the white button mushroom (Agaricus bisporus). Food Chemistry 133: 1538-1543.

Nehru, C. and Kumar, V.J.F. 1995. Solar drying characteristics of Oyster mushroom. Mushroom Research 4: 2730

Nour, V., Trandafir, I. and Ionica, M.E. 2011. Effects of pre-treatments and drying temperatures on the quality of dried button mushrooms. South Western Journal of Horticulture, Biology and Environment 2:15-24.

Oliveira, F., Sousa-Gallagher, M. J., Mahajan, P. V., \& Teixeira, J. A. 2012. Development of shelf-life kinetic model for modified atmosphere packaging of fresh sliced mushrooms. Journal of Food Engineering 111: 466-473.

Rai, R.D. and Arumuganathan, T. 2003. Postharvest handling of the fresh mushrooms. In: Compendium for Summer school on "Emerging areas of mushroom research and production", pp: 301-311, 26th August to 15th September, 2003, NRCM, Solan (H.P).

Rai, R.D., Chandrasekar, V. and Arumuganathan, T. 2003. Post-harvest technology of mushrooms. In: Current vistas in mushrooms biology and production-Proceedings of the IIIrd Indian mushroom conference pp. 225236.

Ranganna, S. 2000. Handbook of analysis and quality control for fruits and vegetable products. Tata McGraw Hill Publishing Co. Ltd., New Delhi.

Sommer, I., Schwartz, H., Solar, S., and Sontag, G. 2010. Effect of gammairradiation on flavour 5'-nucleotides, tyrosine, and phenylalanine in mushrooms (Agaricus bisporus). Food Chemistry 123:171-174.

\section{How to cite this article:}

Pradip Narale, Surendra Kothari and Nafisa Ali. 2018. Drying of Agaricus bisporus Mushroom in Solar-Biogas Hybrid Dryer. Int.J.Curr.Microbiol.App.Sci. 7(04): 1844-1852.

doi: https://doi.org/10.20546/ijcmas.2018.704.210 